ARAŞTIRMA MAKALESI

\title{
Doğum Sonu Dönemde Annelerin Emzirme Öz-Yeterlilik Algıları İle Emzirme Başarıları Arasındaki İlişki
}

\author{
Yahya ERGEZEN ${ }^{1}$,(iD) Emine EFE²,(iD) Fatma ÇALIŞKAN ÖZDÖL ${ }^{3}$,(iD) Şevkiye DİKMEN ${ }^{4}$
}

\begin{abstract}
${ }^{1}$ Arş. Gör., Akdeniz Üniversitesi, Hemşirelik Fakültesi, Çocuk Sağlığı ve Hastalıkları Hemşireliği Anabilim Dalı, Antalya, Türkiye. ${ }^{2}$ Prof. Dr., Akdeniz Üniversitesi, Hemşirelik Fakültesi, Çocuk Sağlığı ve Hastalıkları Hemşireliği Anabilim Dalı, Antalya, Türkiye. ${ }^{3}$ Hemşire, Akdeniz Üniversitesi Hastanesi, Antalya, Türkiye.
\end{abstract}

${ }^{4}$ Hemşire, Akdeniz Üniversitesi Hastanesi, Antalya, Türkiye.

Öz

Giriş: Emzirme, bir bebeği beslemek için en güvenli ve sağlıklı yöntemdir. Annenin ve bebeğinin sağlık sonuçlarının iyileşmesine katkıda bulunur. Amaç: Bu çalışmada doğum sonu dönemde annelerin emzirme öz-yeterlilik algıları ile emzirme başarıları arasındaki ilişkiyi incelemek amaçlanmıştır. Yöntem: Tanımlayıcı tasarımdaki bu araştırmanın örneklemini, Akdeniz Bölgesindeki bir üniversite hastanesinin Kadın Doğum servisinde yatan, sağlıklı yeni doğum yapmış 102 anne oluşturmuştur. Veri toplama aracı olarak; tanımlayıcı veri formu, Emzirme Öz-yeterlilik Ölçeği-kısa şekli, LATCH Emzirme Değerlendirme Aracı kullanılmıştır. Emzirme öz-yeterliliği verileri yüz yüze görüşme yöntemi ile toplanmıştır. Annelerin emzirme başarıları gözlem yöntemi ile değerlendirilmiştir. Bulgular: Araştırma kapsamındaki annelerin \%47.1'inin 26-33 yaşında, \%38.2'si ilkokul mezunu, \%68.6'sı sezaryen ile doğum yapmıs ve \%30.4'ünün ilk doğumu olduğu tespit edilmiștir. Annelerin emzirme öz yeterliği puan ortalaması $57.30 \pm 10.46$ ve emzirme başarıları puan ortalaması $8.38 \pm 1.53$ bulunmuştur. Annelerin emzirme öz yeterliliği ve emzirme başarıları arasında istatistiksel olarak anlamlı bir ilişki olmadığ 1 saptanmıştır $(p=$ $.157, r=.14)$. Annelerin çocuk sayısı ile Emzirme Öz Yeterlilik Ölçeği ve LATCH Emzirme Değerlendirme Aracı puanları arasında anlamlı bir ilişki bulunmuştur $(p<.05)$. Çocuk sayısı arttıkça annelerin emzirme öz yeterliliği ve emzirme başarısının arttığı belirlenmiştir. Sonuç: Yeni doğum yapmış annelerin emzirme döneminde sağlık profesyonelleri ve aile yakınları tarafından desteklenmesinin annelerin emzirme başarılarını ve emzirme öz yeterlilikleri artacağı düşünülmektedir.

Anahtar Sözcükler: Emzirme, Öz Yeterlilik, Anne Sütü.

\section{The Relationship between Mothers' Breastfeeding Self-Efficacy Perceptions and Breastfeeding Success in Postpartum Period}

Background: Breastfeeding is the safest and healthiest way to feed a baby. It contributes to the improvement of the health consequences of the mother and her baby. Objective: This study was planned as a descriptive comparative study to investigate the relationship between breastfeeding self-efficacy perceptions and breastfeeding success of mothers in the postpartum period. Method: The study sample of a university hospital in the south of Turkey lies at the Maternity Service has created 102 healthy female patient who had recently given birth. As a data collection tool; Descriptive data form, Breastfeeding Self-Efficacy Scale-short form, LATCH Breastfeeding Assessment Tool was used. Face-to-face interview method was used to collect descriptive data and breastfeeding self-efficacy scale data. The LATCH Breastfeeding Assessment Tool was evaluated using the observation method at the time of breastfeeding. Results: It was determined that $47.1 \%$ of the mothers within the scope of the study were $26-33$ years old, $38.2 \%$ were primary school graduates, $68.6 \%$ had cesarean section and $30.4 \%$ had their first birth. Breastfeeding self-efficacy mean score of mothers was $57.30 \pm 10.46$ and breastfeeding success mean score was $8.38 \pm 1.53$. There was no statistically significant relationship between breastfeeding self-efficacy and breastfeeding success of the mothers $(\mathrm{p}=.157, \mathrm{r}=.14)$. A significant correlation was found between mothers' number of children and Breastfeeding Self-Efficacy Scale and LATCH Breastfeeding Assessment Tool scores $(\mathrm{p}<.05)$. It was determined that as the number of children increased, breastfeeding selfefficacy and breastfeeding success of mothers increased. Conclusion: It is thought that breastfeeding success and breastfeeding self-efficacy of mothers who support newly mothers by breastfeeding health professionals and family relatives will increase.

Key Words: Breastfeeding, Self-Efficacy, Breast Milk.

Geliş Tarihi / Received: 29.01.2020 Kabul Tarihi / Accepted: 07.06.2021

Correspondence Author: Efe E., Prof. Dr., Akdeniz Üniversitesi, Hemşirelik Fakültesi, Çocuk Sağlığı ve Hastalıkları Hemşireliği Anabilim Dalı, Antalya, Türkiye. Telefon: +905337798302 E-posta: eefe@akdeniz.edu.tr

Cite This Article: Ergezen Y, Efe E, Çalışkan Özdöl F, Dikmen Ş. Doğum Sonu Dönemde Annelerin Emzirme Öz-Yeterlilik Algıları İle Emzirme Başarıları Arasındaki İlişki. Dokuz Eylül Üniversitesi Hemşirelik Fakültesi Elektronik Dergisi. 2021; 14(3): 217- 223 
$\mathbf{E}$ mzirme, bir bebeği beslemek için en güvenli ve sağlıklı yöntemdir. Annenin ve bebeğinin kısa ve uzun vadeli sağlık sonuçlarının iyileşmesine katkıda bulunur (1). Emzirme sadece çocuk ve aile sağlığı yönünden değil toplumun geleceği bakımından da önem arz etmektedir. Sağlıklı anne, sağlıklı çocuk, sağlkklı aile ve sağlıklı toplum ilişkisini ortaya koymaktadır. Bu nedenle yeterli beslenmenin sağlanamadığı durumlarda bebeklerin bir yıldan daha uzun süre emzirilmeleri önerilmektedir.

Anne sütü bebeğin sağlığını koruma ve geliştirmede etkili bir üründür. Anne sütü bebekte gelişebilecek diyare, solunum yolu enfeksiyonları, astım, orta kulak iltihabı gibi sağlık problemlerinin görülme sıklığını ve şiddetini azaltmaktadır (2). Anne sütü, ani bebek ölüm sendromu ve diyabet gibi sorunlara karşı da koruyucudur. Yapılan çalışmalar anne sütünün, bebeğin patojenlere karşı immün sistem bağışıklığını arttırdığını (3), yenidoğan ölüm riskini azalttığını (4), çocukluk çağı obezitesi için koruyucu bir faktör olduğunu (5) ve annede over kanser riskini azalttığını ortaya koymaktadırlar (1).

Anne sütünün hem bebek hem de anne açısından çok sayıda yararı olmasına rağmen emzirmeyi etkileyen birtakım durumlar bulunmaktadır. Anne ve bebek açısından değerlendirildiğinde doğum tipi, anne/çocuktan kaynaklanan komplikasyonlar, anne/yenidoğan arasındaki bağlanma süresi ve zamanı, annenin yaşı, sosyoekonomik durumu, emzirme ile ilișkili davranışları ve emzirme ile ilgili deneyimler etkileyen faktörler arasında gösterilebilir. Yanı sıra emzirme süresince sağlık profesyonellerinin desteği, aile/eş desteği ve hastane rutinleri diğer faktörler arasındadır (6). Fakat, emzirmeyi etkileyen faktörlerin başında annenin emzirmeye ilişkin öz yeterlilik algısı gelmektedir.

Bandura (1995), öz yeterliliği “bir davranış ya da görevi gerçekleştirme konusunda bireyin hissettiği yeterlilik” olarak tanımlamıştır. Emzirme öz yeterlilik algısı ise annenin emzirmeye ilişkin hissettiği yeterlilik olarak nitelendirilmektedir (7). Annenin emzirme öz yeterliliği, annenin yeni bebeğini emzirebilmesi ya da emzirmeye güvenmesi gibi algılanan bir yetenek olarak da tanımlanmaktadır (8). Emzirme öz yeterliliği, doğum sonrası dönemde emzirme sonuçlarını etkileyen önemli bir faktör olarak vurgulanmıştır $(8,9)$. Yapılan araştırmalar emzirme öz yeterliliğinin emzirmenin başlatılması ve süresi ile ilgili önemli bir faktör olduğunu göstermiştir (9). Yapılan bir çalışmada, doğum sonrası bebeklerin yeterli miktarda anne sütü alma durumları değerlendirilmiş olup, term bebeklerin her beslenme sırasında almaları gereken süt hacminin \%95.4'ünü tüketebildiği buna karşın bu oranın preterm bebeklerde sadece $\% 45$ olduğu bildirilmişstir (10).

Emzirme yeterliliği, doğru emzirme tekniği, bebek tarafindan etkin olmayan emme, emzirme sıklığının az olması, süt kanalının tıkanması ve bebeğin anneden ayrılması gibi faktörlerden etkilenmektedir. Bu faktörler, doğum sonrası dönemin başlarında sağlık profesyonelleri tarafından değerlendirilmelidir (11). Yapılan çalışmalar, sağlık profesyonelleri tarafından desteklenen annelerin emzirme kapasitelerinin arttığını göstermektedir $(11,12)$. Literatürde annenin emzirme öz yeterliliği ile ilgili çok sayıda çalışma bulunmaktadır (13-16). Ancak annelerin emzirme öz-yeterliliği ile emzirme başarıları arasındaki ilişkiyi karşılaştıran sınırlı sayıda çalışmaya rastlanmıştır (6-7).

Sağglıklı bireylerin yetiştirilebilmesi için bebeklerin anne sütünü yeterli miktarda alması anne, bebek ve toplum sağlı̆̆ı açısından son derece önemli bir konudur (7). Emzirmeye ilişkin öz yeterliliğin geliştirilmesinde annenin desteklenmesi, emzirme konusunda cesaretlendirilmesi, yeterli düzeyde bilgi alması ve bu beceriyi uygulaması gerekmektedir. Anne bu süreçte fiziksel, emosyonel, spiritüel ve sosyal desteğe gereksinim duymaktadır. Sağlık profesyonelleri özellikle hemşireler anneyi güçlendirme, destekleme, danışmanlık ve rehberlik aşamasında kilit pozisyondadır. Hemşirelerin emzirme başarısını etkileyen faktörleri bilmesi ve buna yönelik uygun girişimler geliştirebilmesi çok önemlidir. Bu araştırma ile annelerin emzirme öz yeterlilikleri ve emzirme başarıları arasındaki ilişki değerlendirilerek literatüre katkı sağlayacağı ve yapılacak olan girişimsel çalışmalara yön vereceği düşünülmektedir. Ayrıca, klinik alanda annenin öz yeterliliğini ve emzirme başarısını geliştirecek yöntemlerin geliştirilmesi, bireye özgü bakımın planlanması ve klinikte rutin bir değerlendirme yöntemi olarak kullanılması açısından yararlı olacağı düşünülmektedir.

Amaç

Araştırma doğum sonu dönemde annelerin emzirme öz-yeterlilik algıları ile emzirme başarıları arasındaki ilişkiyi araştırmak amacıyla tanımlayıcı karşılaştırmalı bir çalışma olarak planlanmıştır.

\section{Araştırma Sorulart:}

- Doğum sonu dönemde annelerin emzirme öz-yeterlilik algıları ile emzirme başarıları arasındaki ilişki nedir?

- Annelerin emzirme öz yeterliliği ve emzirme başarılarını etkileyen değişkenler nelerdir?

\section{Araştırmanın Tipi}

\section{Yöntem}

Araştırma doğum sonu dönemde annelerin emzirme öz-yeterlilik algıları ile emzirme başarıları arasındaki ilişkiyi incelemek amacıyla tanımlayıcı karşılaştırmalı olarak planlanmıştır.

\section{Araştırmanın Yapıldiğ Yer ve Zaman}

Araştırma Akdeniz Bölgesinde bir üniversite hastanesinin kadın doğum servisinde, Mayıs 2018- Ekim 2018 tarihleri arasında yürütülmüştür.

\section{Araştırmanın Evreni/Örneklemi}

Araştırmanın evrenini araştırmanın yürütüldüğü hastanenin kadın doğum servisinde yatan sağlıklı yeni doğum yapmış olan anneler oluşturmuştur. Araştırmanın verileri, belirtilen tarihler arasında kadın doğum servisine yatan 102 anne ile tamamlanmıştır. Son bir yıl içerisinde servise yatışı yapılan araştırmanın dahil edilme kriterlerine uyan anne sayısı tam olarak bilinmediğinden araştırmada örneklem büyüklüğ̈̈, evrendeki kişi sayısının bilinmediği durumlardaki formül $\left(n=t^{2} . \sigma^{2} / d^{2}\right)$ kullanılarak, Yenal ve ark. (7) yaptığı çalışmadaki emzirme öz yeterlilik ölçeği-kısa formu standart sapma değeri (SD = 8.46) dikkate alınarak hesaplanmış ve 98 kişi bulunmuştur. 
Araştırmanın dahil edilme kriterleri; 18 yaşından büyük, okuma yazma bilen, Türkçe konuşabilen, miadında ve sağlıklı doğum yapan (38-42 haftalık, 2500- 4000 gr doğan, 5. dakika APGAR puanı 7 ve üzerinde doğan, bilinen konjenital hastalığ olmayan), emziren ve emzirmeye engel bir kronik hastalığı olmayan kadınlar araştırmaya alınmıştır.

\section{Veri Toplama Araçlart-Geçerlik ve Güvenirlik Bilgileri}

Veri toplama aracı olarak; tanımlayıcı veri formu, Emzirme Öz-Yeterlilik Ölçeği-Kısa Formu, LATCH emzirme değerlendirme aracı kullanılmıştır.

Tanımlayıcı Veri Formu: Bu form kadınların sosyo-demografik ve obstetrik özellikleri ile önceki emzirme deneyimlerini saptamak amacıyla oluşturulmuştur. Tanımlayıcı veri formunda 12 soru yer almaktadır. Form literatüre dayalı olarak araştırmacılar tarafından geliştirilmiştir $(7,8,16,17)$.

Emzirme Öz-Yeterlilik Ölçeği-Kısa Form: Emzirme Öz-Yeterliliği Ölçeği ilk olarak Dennis ve Fauz (18) tarafından 33 maddelik bir ölçek olarak geliştirilmiştir. Bu ölçek, annelerin emzirmeye ilişkin kendilerini ne kadar yeterli hissettiklerini değerlendirmektedir. Ölçekte yer alan tüm maddeler pozitif anlam taşımaktadır. Yapılan pilot çalışmada Cronbach alfa değeri .96 bulunmuştur. Dennis ve Fauz (18) tarafindan yapılan iç tutarlık analizine göre madde fazlalığı olduğu saptanmış ve analizler sonucunda madde-toplam korelasyonu .60'ın altında olan maddeler çıkarılarak 14 maddelik yeni Emzirme Öz-Yeterlilik Ölçeği'nin kısa şekli oluşturulmuştur. Bu ölçeğe ait kısa formun Cronbach alfa değeri .94 bulunmuştur. Yapılan çalışmalarda Emzirme Öz-Yeterliliği Ölçeğinin annelerde doğum sonrası kullanıldığı görülmüştür $(17,19)$. Bu çalışmada ise veriler doğumdan sonra 24. ve 48. saatler arasında toplanmıştır. Ölçek 5'li likert tipte olup, hiç emin değilim (1 puan) ve her zaman eminim (5 puan) şeklinde değerlendirilmektedir. Ölçekten minimum alınabilecek puan 14 ve maksimum puan 70'tir. Ölçeğin Türkçe'ye uyarlanması Tokat ve ark. (17) tarafından yapılmıştır. Tokat ve ark. (17) yaptıkları çalışmada ölçeğin Cronbach alfa değeri .86 bulunup, güvenilir bir ölçek olduğu saptanmıștır. Bu araştırmada Cronbach alfa değeri .88 olarak bulunmuştur $(\mathrm{n}=102)$.

LATCH Emzirme Değerlendirme Aracı: Emzirmenin değerlendirilmesinde kullanılan ölçüm araçlarından biri LATCH'tır. LATCH Emzirme Değerlendirme Aracı 1986 yılında puanlama yöntemi açısından APGAR skor sistemine benzetilerek oluşturulan bir araçtır. Değerlendirmesi hızlı ve kolaydır. Bu ölçüm aracı, emzirme tanılamasını objektif olarak yapmak, emzirme problemlerini saptamak ve eğitim planı yapmak, sağlık çalışanları arasında ortak dil oluşturmak ve araştırmalarda kullanılmak üzere geliştirilmiştir. Bu ölçüm aracı beş değerlendirme kriterinden oluşmakta olup, bu kriterlerin İngilizce karşılığının ilk harflerinin birleşiminden oluşmaktadır. Her madde 0-2 puan arasında değerlendirilmektedir. Ölçüm aracından alınabilecek toplam puan 10'dur. Ölçüm aracının kesme noktası yoktur. LATCH puanı yükseldikçe emzirme başarısının yüksek olduğu anlaşılmaktadır. Türkiye'de güvenirliği Yenal ve Okumuş (19) tarafindan yapılmış ve Chronbach alfa değeri .95 olarak saptanmıştır. Bu araştırmada Cronbach alfa değeri .72 olarak bulunmuştur $(n=102)$.

\section{Araştırmanın Uygulanması \\ Tanımlayıcı verilerin ve emzirme öz-yeterlilik ölçek verilerinin toplanmasında yüz yüze görüşme yöntemi kullanılmıştır. LATCH Emzirme Değerlendirme Aracının değerlendirilmesi emzirme anında gözlem metodu kullanılarak yapılmıştır. Emzirme anı araştırmacılar tarafından gözlemlenmiştir. Emzirme gözlenirken doğum sonrası 24-48 saatleri arasındaki herhangi bir spontan emzirme zamanı beklenmiştir. Bu zamanın beklenilmesinin sebebi emzirmeye ilişkin kaygıların doğum sonrası erken dönemde en yoğun yaşandığı zaman olmasıdır. Herhangi bir müdahalede bulunmadan emzirme izlenmiş ve LATCH emzirme değerlendirme aracı araştırmacı tarafından anında doldurulmuştur.}

\section{Verilerin Değgerlendirilmesi}

Verilerin değerlendirilmesinde SPSS 20.0 (Statistical Package for the Social Sciences) paket programı kullanılmıştır. Tanımlayıcı özellikleri değerlendirmek için sayı, yüzde ve ortalama kullanılmıştır. Emzirme Öz Yeterliliği Ölçeği skorları ile LATCH emzirme değerlendirme aracı skorları arasındaki ilişki korelasyon analizi ile değerlendirilmiştir. Veriler normal dağılmadığı için Spearman korelasyon analizi kullanılmıştır. Emzirme Öz-Yeterliliği Ölçeği ve LATCH puanlarını etkileme olasılığı olan bağımsız değişkenler (yaş, eğitim, gelir düzeyi, doğum tipleri, doğum sayısı) için parametrik olmayan Kruskal Wallis-H testi kullanılarak analiz yapılmıştır. Emzirme Öz-Yeterliliği Ölçeği ve LATCH puanlarını etkileme olasılığı olan bağımsız değişkenler (çalışma durumu, doğum şekli) için parametrik olmayan Mann-Whitney U testi kullanılarak analiz yapılmıştır. Çalışmada $p<.05$ istatistiksel anlamlılık olarak kabul edilmiştir.

\section{Araştırmanın Etik Yönü}

Araştırmanın yürütüldüğü üniversitenin Girişimsel Olmayan Klinik Araştırmalar Etik Kurul komisyonundan etik izin (Tarih:16.04.2018-No:70904504/156) alınmıştır. Daha sonra araştırmanın yapılacağı üniversitesi hastanesinden yazılı izin (Tarih: 22.05.2018) alınmıştır. Araştırmaya seçilen örneklemde gönüllülük esas alınarak araştırmaya katılmayı kabul eden bireylere araştırmanın amacı ve uygulanması hakkında bilgilendirilme yapılmış, yazılı ve sözlü izin alınmıştır. Araştırmanın her aşamasında yayın etik ilkelerine uyulmuştur.

\section{Bulgular}

Araştırmaya katılan annelerin tanımlayıcı özelliklerinin dağılımı Tablo 1'de gösterilmiştir. Araştırma kapsamındaki annelerin \%47.1'inin 26-33 yaş aralığında olduğu görülmektedir. Annelerin \%38.2'sinin ilkokul mezunu olduğu ve \%67.6'sının da herhangi bir işte çalışmadığı belirlenmiştir. Annelerin büyük çoğunluğunun (\%70.6) ekonomik durumunun orta düzeyde olduğu saptanmıştır. 
Tablo 1. Annelerin Demografik ve Doğumla İlgili Özellikleri $(n=102)$

\begin{tabular}{lc}
\hline Değişkenler & $\mathbf{n}(\mathbf{\%})$ \\
\hline Yaş & $28(27.5)$ \\
$18-25$ & $48(47.1)$ \\
$26-33$ & $26(25.4)$ \\
34 ve üstü & \\
\hline Ĕgitim durumu & $7(6.9)$ \\
Okur-yazar & $39(38.2)$ \\
İlkokul & $33(32.4)$ \\
Lise & $23(22.5)$ \\
Lisans ve üzeri & \\
\hline Çalışma durumu & $33(32.4)$ \\
Evet & $69(67.6)$ \\
Hayır & \\
\hline Gelir durumu & $8(7.8)$ \\
Kötü & $72(70.6)$ \\
Orta & $22(21.6)$ \\
İyi & \\
\hline Doğum şekli & $32(31.4)$ \\
Normal doğum & $70(68.6)$ \\
Sezaryen & \\
\hline Gebelik sayısı & $31(30.4)$ \\
Bir & $28(27.5)$ \\
İki & $22(21.6)$ \\
Üç & $21(20.5)$ \\
\hline Dört ve üzeri &
\end{tabular}

Emzirme Öz Yeterlilik Ölçeği ve LATCH Emzirme Değerlendirme Aracı arasındaki ilişki Tablo 2'de verilmiştir. Emzirme Öz Yeterlilik Ölçeği ortalama puanı 57.30 (SD = 10.46), LATCH Emzirme Değerlendirme Aracı ortalama puanı 8.38 $(S D=1.53)$ olarak belirlenmiştir. Emzirme Öz Yeterlilik Ölçeği ve LATCH Emzirme Değerlendirme Aracı arasında anlamlı bir ilişkinin olmadığı saptanmıştır $(p=.157, r=.14)$.

Tablo 2. Annelerin Emzirme Öz Yeterlilik Ölçeği Puanları İle LATCH Puanları Arasındaki Korelasyon

\begin{tabular}{|c|c|c|c|c|c|c|}
\hline Ölçek & $\mathbf{n}$ & Ortalama (SD) & Alt & Üst & $\mathbf{r}$ & $\mathbf{p}$ \\
\hline $\begin{array}{l}\text { Emzirme Öz } \\
\text { Yeterlilik } \\
\text { Ölçeği-kısa şekli }\end{array}$ & 102 & $57.30(10.46)$ & 16 & 117 & .14 & .157 \\
\hline $\begin{array}{l}\text { LATCH } \\
\text { Emzirme } \\
\text { Değerlendirme } \\
\text { aracı }\end{array}$ & 102 & $8.38(1.53)$ & 4 & 10 & & \\
\hline
\end{tabular}

Araştırmaya katılan annelerin tanımlayıcı özellikleri ile Emzirme Öz Yeterlilik Ölçeği ve LATCH Emzirme Değerlendirme Aracı puanları arasındaki ilişki Tablo 3'de gösterilmiştir. Annelerin yaşları, eğitim düzeyi, çalışma durumu, gelir durumu ve doğum şekli ile Emzirme Öz Yeterlilik Ölçeği ve LATCH Emzirme Değerlendirme Aracı puanları arasında anlamlı bir ilişki bulunmamıştır $(p>.05)$. Annelerin çocuk sayısı ile Emzirme öz yeterlilik ölçeği puan ortalamaları arasında istatistiksel olarak anlamlı bir fark olduğu tespit edilmiştir $\left(X^{2}=6.518 p=.038\right)$. Benzer şekilde annelerin çocuk sayısı ile LATCH Emzirme Değerlendirme Aracı puan ortalamaları arasında istatistiksel olarak anlamlı bir fark olduğu tespit edilmiştir $\left(\mathrm{X}^{2}=9.20 \mathrm{p}=.019\right)$. Çocuk sayısı arttıkça annelerin emzirme öz yeterliliği ve emzirme başarısının arttığı saptanmıştır. Söz konusu farkın hangi gruptan kaynaklandığını belirlemek amacıyla çoklu karşılaştırma yapılmıştır. Üç ve üzeri çocuğu olan annelerin emzirme öz yeterliliği ve emzirme başarısı puan ortalamasının, bir çocuğu olan annelerden daha yüksek olduğu belirlenmiştir (Tablo 3). 
Tablo 3. Annelerin Demografik Özellikleri İle Emzirme Öz Yeterlilik Ölçeği ve LATCH Emzirme Değerlendirme Aracı Skorları Arasındaki İlișki

\begin{tabular}{|c|c|c|c|c|c|}
\hline Değişkenler & $\mathbf{n}$ & $\begin{array}{c}\text { Emzirme Öz } \\
\text { Yeterlilik Ölçeği- } \\
\text { kısa şekli (Ort } \pm \\
\text { SD) } \\
\end{array}$ & $\begin{array}{c}\text { Test } \\
\mathbf{p}\end{array}$ & $\begin{array}{c}\text { LATCH Emzirme } \\
\text { Değerlendirme } \\
\text { Aracı (Ort } \pm \text { SD) }\end{array}$ & $\begin{array}{c}\text { Test } \\
\mathbf{p}\end{array}$ \\
\hline $\begin{array}{l}\text { Yaş grupları } \\
18-25 \\
26-33 \\
34 \text { ve üstü }\end{array}$ & $\begin{array}{l}28 \\
48 \\
26\end{array}$ & $\begin{array}{c}55.42 \pm 10.66 \\
58.58 \pm 11.55 \\
56.96 \pm 7.87\end{array}$ & $\begin{array}{c}K W=.21 \\
p=.899\end{array}$ & $\begin{array}{l}8.21 \pm 1.68 \\
8.41 \pm 1.47 \\
8.50 \pm 1.52\end{array}$ & $\begin{array}{c}K W=.31 \\
p=.855\end{array}$ \\
\hline $\begin{array}{l}\text { Eğitim durumu } \\
\text { Okur-yazar } \\
\text { İlkokul } \\
\text { Lise } \\
\text { Lisans üstü }\end{array}$ & $\begin{array}{c}7 \\
39 \\
33 \\
23\end{array}$ & $\begin{array}{c}52.14 \pm 16.93 \\
57.41 \pm 8.49 \\
57.90 \pm 13.19 \\
57.82 \pm 6.15\end{array}$ & $\begin{array}{c}K W=.36 \\
p=.947\end{array}$ & $\begin{array}{l}8.28 \pm 1.97 \\
8.25 \pm 1.61 \\
8.63 \pm 1.51 \\
8.26 \pm 1.32\end{array}$ & $\begin{array}{c}K W=2.05 p= \\
.562\end{array}$ \\
\hline $\begin{array}{l}\text { Çalışma durumu } \\
\text { Evet } \\
\text { Hayır }\end{array}$ & $\begin{array}{l}33 \\
69 \\
\end{array}$ & $\begin{array}{c}58.18 \pm 13.24 \\
56.88 \pm 8.92 \\
\end{array}$ & $\begin{array}{c}z=1095.00 \\
p=.755\end{array}$ & $\begin{array}{l}8.27 \pm 1.77 \\
8.43 \pm 1.41 \\
\end{array}$ & $\begin{array}{c}z=1128.50 \\
p=.941\end{array}$ \\
\hline $\begin{array}{l}\text { Gelir durumu } \\
\text { Kötü } \\
\text { Orta } \\
\text { İyi }\end{array}$ & $\begin{array}{c}8 \\
72 \\
22\end{array}$ & $\begin{array}{c}58.37 \pm 7.90 \\
55.52 \pm 9.01 \\
62.72 \pm 13.76\end{array}$ & $\begin{array}{c}K W=6.84 \\
p=.033\end{array}$ & $\begin{array}{l}8.87 \pm 1.35 \\
8.33 \pm 1.52 \\
8.36 \pm 1.64\end{array}$ & $\begin{array}{c}K W=0.95 \\
p=.622\end{array}$ \\
\hline $\begin{array}{l}\text { Doğum şekli } \\
\text { Normal doğum } \\
\text { Sezaryen }\end{array}$ & $\begin{array}{l}32 \\
70 \\
\end{array}$ & $\begin{array}{c}58.43 \pm 7.29 \\
56.78 \pm 11.64 \\
\end{array}$ & $\begin{array}{c}z=971.50 \\
p=.284\end{array}$ & $\begin{array}{l}8.59 \pm 1.31 \\
8.28 \pm 1.62 \\
\end{array}$ & $\begin{array}{c}z=1030.50 \\
p=.507\end{array}$ \\
\hline $\begin{array}{l}\text { Çocuk sayısı } \\
1 \\
2 \\
3 \text { ve üzeri }\end{array}$ & $\begin{array}{l}41 \\
40 \\
21\end{array}$ & $\begin{array}{c}54.97 \pm 7.83 \\
58.10 \pm 13.22 \\
60.33 \pm 8.24\end{array}$ & $\begin{array}{c}K W=6.518 \\
p=.038\end{array}$ & $\begin{array}{l}7.85 \pm 1.71 \\
8.57 \pm 1.44 \\
9.04 \pm 0.92\end{array}$ & $\begin{array}{c}K W=9.20 \\
p=.019\end{array}$ \\
\hline
\end{tabular}

*KW:Kruskal Wallis H Testi sonucu

**z:Mann-Whitney U Testi sonucu

\section{Tartışma}

Bu araştırmada annelerin Emzirme Öz Yeterlilik Ölçeği puan ortalamaları ile LATCH Emzirme Değerlendirme Aracı puan ortalamaları arasında anlamlı bir ilişki bulunamamıştır. Yenal ve ark. (7) yaptıkları çalışmada emzirme öz yeterlilik ölçeği puan ortalamaları ile LATCH Emzirme Değerlendirme Aracı puan ortalamaları arasında istatistiksel olarak anlamlı, pozitif yönde ve orta düzeyde bir ilişki olduğunu saptamışlardır. Gerçek ve ark. (6) yaptıkları çalışmada Emzirme Öz Yeterlilik Ölçeği puan ortalamaları ile LATCH Emzirme Değerlendirme Aracı puan ortalamaları arasında istatistiksel olarak anlamlı, pozitif yönde ve zayıf bir ilişki olduğunu bildirmişlerdir. Bu çalışma sonuçlarının bizim araştırma sonuçlarını desteklemediği görülmektedir. Bunun nedeninin yapılan diğer çalışmaların örneklem sayılarının fazla olmasından kaynaklandığı düşünülmektedir. Bizim çalışmamız 102 örneklem, Yenal ve ark. (7) çalışması 220 örneklem, Gerçek ve ark. (6) 303 örneklem ile yapılmıştır.

Kocaöz, Destegül ve Kocaöz (20) yaptıkları çalışmada anestezi tipi ile Emzirme Öz Yeterlilik Ölçeği puan ortalamaları ve LATCH Emzirme Değerlendirme Aracı puan ortalamaları arasında anlamlı bir ilişki olmadığını bildirmişlerdir. Bizim çalışmamızda da doğum şekli ile Emzirme Öz Yeterlilik Ölçeği puan ortalamaları ve LATCH Emzirme Değerlendirme Aracı puan ortalamaları arasında anlamlı bir ilişki olmadığı belirlenmiştir. Araştırma verilerinin doğumdan sonra 24-48 saatler arasından toplanmış olmasından dolayı doğum şekli ile Emzirme Öz Yeterlilik Ölçeği puan ortalamaları ve LATCH Emzirme Değerlendirme Aracı puan ortalamaları arasında anlamlı bir ilişki olmasına neden olmuş olabilir.

Emzirmeyi etkileyen faktörleri doğumun tipi, anne ve çocuktan kaynaklanan komplikasyonlar, emzirme süresince sağlık profesyonellerinin desteği, aile ve eş desteği, anne ve yenidoğan arasındaki bağlanma süresi ve zamanı, hastane rutinleri olarak sıralanabilir. Bunlara ek olarak annenin yaşı, sosyoekonomik durum, emzirme ile ilişkili davranışlar, emzirme ile ilgili deneyimler emzirmeyi etkileyen faktörler arasında gösterilebilir (6). Aydın ve Aba (21) yaptıkları çalışmada doğum şekli ve emzirme öz yeterliliği arasında anlamlı bir ilişki olmadığını belirtmişlerdir. Bizim araştırmamızda annelerin yaşları, eğitim düzeyi, çalışma durumu, gelir durumu ve doğum şekli ile Emzirme Öz Yeterlilik Ölçeği ve LATCH Emzirme Değerlendirme Aracı puan ortalamaları arasında anlamlı bir ilişki bulunmamıştır $(p>.05)$. Gerçek ve ark. (6) yaptıkları çalışmada bizim araştırmamıza benzer şekilde sonuçlar bulmuşlardır. Hemşireler, annelerin emzirme davranışlarını birebir gözlemleyebilme olanağına sahip olduklarından emzirme öz yeterlilik algısının yükseltilmesinde önemli role sahiptirler. Hemşireler tarafindan emzirme danışmanlığı yapılması, emzirme sorunlarının çözümlenebilmesi açısından önemlidir (26).

Bu araştırmada annelerin çocuk sayısı ile Emzirme Öz Yeterlilik Ölçeği ve LATCH Emzirme Değerlendirme Aracı puan ortalamaları arasında anlamlı bir ilişki bulunmuştur $(p<.05)$. Çocuk sayısı arttıkça annelerin emzirme öz yeterliliği ve emzirme başarısının arttığı saptanmıştır. Türk kültüründe anneler, aile büyükleri tarafından emzirilmeleri konusunda kuvvetle teşvik edilmekte ve doğum sonrası dönemde daha uzun süre emzirme deneyimleri ortaya çıkmaktadır (22). Aluş Tokat ve ark. 
(22) çalışmamıza benzer şekilde önceki çocuklarını emziren annelerin daha sonraki çocuklarını da emzirdiklerini ortaya koymuşlardır. Çocuk sayısı arttıkça annelerin emzirme eğilimlerinin ve emzirme başarılarının arttığını belirtilmektedir. Zhu ve diğ. (9) daha önce emzirme deneyimi olan, diğer annelerin bebeklerini emzirmelerini izleyen veya daha önce emzirmeye karar veren annelerin emzirme öz yeterliliğinin daha yüksek olduğunu belirtmişlerdir. Mevcut literatür, psikososyal unsurların annelerin emzirme öz yeterliklerini ve emzirme yeteneklerini etkilemede büyük öneme sahip olduğu fikrini desteklemektedir $(23,24)$. Yapılan çalışmalar, annelerin emzirme öz yeterliği ve emzirme yeterliliğinin, doğum öncesi dönemde öz yeterlilik temelli hemşirelik müdahaleleri, dikkat temelli eğitim, ev temelli video konferansı, eğitim ve telefon desteği ile arttırılabileceğini göstermiştir $(14,18,21,25,26)$. Bu bağlamda araştırmamızın annelerin emzirme öz yeterlilikleri ve emzirme başarıları arasındaki ilişkinin değerlendirilmesi ile literatüre katkı sağlayacağı ve yapılacak olan girişimsel çalışmalara yön vereceği düşünülmektedir.

\section{Kisıtlılıklar}

Araştırma yalnızca bir üniversite hastanesinin kadın doğum servisinde yapıldığından dolayı genellenebilirliği açısından sınırlılık olarak kabul edilebilir. Bununla birlikte, örneklem sayısının yapılan diğer çalışmalara göre az olması ve gözlem işleminin tek araştırmacı ile yapılması sınırlılık olarak kabul edilebilir.

\section{Sonuçların Uygulamada Kullanımı}

Bu çalışmada annelerin emzirme öz yeterlilikleri ve emzirme başarıları arasında anlamlı bir ilişki olmadığı, fakat daha önce emzirme deneyimi yaşayan annelerin emzirme öz yeterlilikleri ve emzirme başarılarının yüksek olduğu sonucu elde edilmiştir. $\mathrm{Bu}$ bağlamda yeni doğum yapmış annelerin emzirme döneminde sağlık profesyonelleri ve aile yakınları tarafından desteklenmesinin annelerin emzirme başarılarını ve emzirme öz yeterliliklerinin artacağı düşünülmektedir. Yenidoğan kliniğinde tedavi edilen bebeklerin ilk emzirme girişiminde emzirme öz-yeterlilik ölçeği ve LATCH Emzirme Değerlendirme Aracı uygulanarak risklerin önceden belirlenmesi, emzirme açısından riskli anneler tanımlandıktan sonra bu annelerin sağlık profesyonelleri tarafindan desteklenmesi yararlı olabilir.

\section{Bilgilendirme}

Yazarların katkı oranı beyanı şöyledir: fikir EE; tasarım EE, YE; Denetim EE, YE, FÇÖ, ŞD; Kaynaklar EE, YE, FÇÖ, ŞD; veri toplanması ve/veya işlenmesi FÇÖ, ŞD; analiz ve/veya yorum YE, EE; literatür taraması EE, YE; yazma EE, YE; eleştirel inceleme EE, YE. Yazarlar arasında herhangi bir çıkar çatışması bulunmamaktadır.

Araştırmacılar bu çalışma için finansal destek almamıştır. Araştırmanın bütçesi araştırmacılar tarafindan karşılanmıştır. Çalışma için etik komite onayı, araştırmanın yapılacağı üniversitesinin Girişimsel Olmayan Klinik Çalışmalar Etik Kurulu'ndan (Tarih:16.04.2018-No:70904504/156) alınmıştır.

Araştırmaya katılmayı kabul eden tüm annelere teşekkür ederiz. 


\section{Kaynaklar}

1. McLain AC, Frongillo EA, Hess SY, Piwoz EG. Comparison of methods used to estimate the global burden of disease related to undernutrition and suboptimal breastfeeding. Adv Nutr 2019;10(3):380-390.

2. Alioğulları AS, Esencan TY, Ünal A, Şimşek Ç. Anne sütünün faydalarını ve emzirme tekniklerini içeren görsel mesaj içerikli broşür ile annelere verilen eğitimin etkinliğinin değerlendirilmesi. Anadolu Hemşirelik ve Sağlık Bilimleri Dergisi 2016;19(4):252-260.

3. Stuebe AM, Schwarz EB. The risks and benefits of infant feeding practices for women and their children. J Perinatol 2010;30(3):155.

4. Khan J, Vesel L, Bahl R, Martines J. Timing of breastfeeding initiation and exclusivity of breastfeeding during the first month of life: Effects on neonatal mortality and morbidity a systematic review and metaanalysis. Matern Child Health J 2015;19(3):468-479.

5. Vazquez CE, Cubbin C. Associations between breastfeeding duration and overweight/obese among children aged 5-10: A focus on racial/ethnic disparities in California. AIMS Public Health 2019;6(4):355.

6. Gerçek E, Sarıkaya Karabudak S, Ardıç Çelik N, Saruhan A. The relationship between breastfeeding self-efficacy and LATCH scores and affecting factors. J Clin Nurs 2017;26(7-8):994-1004.

7. Yenal K, Aluş Tokat M, Durgun Ozan Y, Çeçe Ö, Bakılan Abalın F. Annelerin emzirme öz yeterlilik algıları ile emzirme başarıları arasındaki ilişkinin incelenmesi. Hemşirelikte Eğitim ve Araştırma Dergisi 2013;10(2):14-19.

8. Huang Y, Ouyang YQ, Redding SR. Previous breastfeeding experience and its influence on breastfeeding outcomes in subsequent births: A systematic review. Women Birth 2019;32(4):303-309.

9. Zhu J, Chan WCS, Zhou X, Ye B, He HG. Predictors of breastfeeding self-efficacy among Chinese mothers: A crosssectional questionnaire survey. Midwifery 2014;30(6):705-711.

10. Altuntas N, Kocak M, Akkurt S, Razi HC, Kislal, MF. LATCH scores and milk intake in preterm and term infants: A prospective comparative study. Breastfeeding Medicine 2015;10(2):96-101.

11. Sahin H, Yılmaz M, Aykut M, Balcı E, Sağıroğlu M, Özturk, A. Risk factors for breastfeeding problems in mothers who presented to two public healthcare centers in Kayseri province. Turk Pediatri Ars 2013;48:145-151.

12. Hannula L, Kaunonen M, Tarkka MT. A systematic review of professional support interventions for breastfeeding. J Clin Nurs 2008;17(9):1132-1143.

13. Ansari S, Abedi P, Hasanpoor S, Bani S. The effect of interventional program on breastfeeding selfefficacy and duration of exclusive breastfeeding in pregnant women in Ahvaz, Iran. Int Sch Res Notices 2014;1-6.

14. Wu DS, Hu J, McCoy TP, Efird JT. The effects of a breastfeeding selfefficacy intervention on short term breastfeeding outcomes among primiparous mothers in Wuhan, China. J Adv Nurs 2014;70(8):1867-1879.

15. Gökçeoğlu E, Küçükoğlu S. The relationship between insufficient milk perception and breastfeeding self-efficacy among Turkish mothers. Global Health Promotion 2017;24(4):53-61.

16. Laliberte C, Dunn S, Pound C, Sourial N, Yasseen AS, Millar D et al. A randomized controlled trial of innovative postpartum care model for motherbaby dyads. PLoS One 2016;11(2):148-520.

17. Aluş Tokat M, Okumuş H, Dennis CL. Translation and psychometric assessment of the Breast-feeding Self-Efficacy Scale-Short Form among pregnant and postnatal women in Turkey. Midwifery 2010;26(1):101-108.

18. Dennis CL, Fauz S. Development and psychometric testing of the Breastfeeding Self-Efficacy Scale. Res Nurs Health 1999; 22(5): 399-409.

19. Yenal K, Okumus H. Emzirme tanılama ölçeğinin güvenilirliğini inceleyen bir çalışma [A study of the reliability of LATCH breastfeeding assessment tool]. Journal of Nursing Research Development 2003;5:38-44.

20. Kocaöz FŞ, Destegül D, Kocaöz S. Comparison of the breastfeeding outcomes and self-efficacy in the early postpartum period of women who had given birth by cesarean under general or spinalanesthesia. J Matern Fetal Neonatal Med 2021; 34(10):1545-1549.

21. Aydın D, Aba YA. Annelerin sağlık okuryazarlığı düzeyleri ile emzirme öz-yeterlilik algıları arasındaki ilişki. DEUHFED 2019;12(1):31-39.

22. Aluş Tokat M, Serçekuş P, Yenal K, Okumuş H. Early postpartum breast-feeding outcomes and breast-feeding self-efficacy in turkish mothers undergoing vaginal birth or cesarean birth with different types of anesthesia. Int J Nurs Knowl 2015;26(2):73-79.

23. Ku CM, Chow SK. Factors influencing the practice of exclusive breastfeeding among Hong Kong Chinese women: A questionnaire survey. J Clin Nurs 2010;19(17-18):34-45.

24. Brown A, Raynor P, Lee M. Healthcare professionals' and mothers' perceptions of factors that influence decisions to breastfeed or formula feed infants: A comparative study. J Adv Nurs 2011;67(9):1993-2003.

25. Aluş Tokat M, Okumus H. Emzirme öz-yeterlilik algısını güçlendirmeye temelli antenatal eğitimin emzirme öz-yeterlilik algısına ve emzirme başarısına etkisi. Hemşirelikte Eğitim ve Araştırma Dergisi 2013;10(1):21-30.

26. Rojjanasrirat W, Nelson EL, Wambach KA. A pilot study of home-based videoconferencing for breastfeeding support. J Hum Lact 2012;28(4):464-467 